Greece \& Rome (2021), 68.2 239-254 Copyright (C) The Author(s), 2021. Published by Cambridge University Press on behalf of The Classical Association. This is an Open Access article, distributed under the terms of the Creative Commons Attribution-NonCommercial-ShareAlike licence (http:// creativecommons.org/licenses/by-nc-sa/4.0/), which permits non-commercial re-use, distribution, and reproduction in any medium, provided the same Creative Commons licence is included and the original work is properly cited. The written permission of Cambridge University Press must be obtained for commercial re-use.

doi:10.1017/S001738352100005X

\title{
WINE TABOO REGARDING WOMEN IN ARCHAIC ROME, ORIGINS OF ITALIAN VITICULTURE, AND THE TASTE OF ANCIENT WINES*
}

\begin{abstract}
A number of ancient sources suggests that Roman women in the archaic period were not allowed to drink wine. Various theories have so far been proposed to explain this taboo, most of them assuming that it meant a complete alcohol ban, and relating it to the special role of women in the Roman family. However, a reconsideration of these theories, which takes into account the results of recent studies on the origins of wine consumption in Italy, shows that the archaic wine taboo had more to do with the nature of wine than with the nature of women.
\end{abstract}

Fetere multo Myrtale solet uino, sed fallat ut nos, folia deuorat lauri merumque cauta fronde, non aqua, miscet.

Hanc tu rubentem prominentibus uenis quotiens uenire, Paule, uideris contra, dicas licebit 'Myrtale bibit laurum.'

Myrtale is wont to smell of deep draughts of wine;

but, to deceive us, she eats bay-leaves, and cautiously mingles them in her cups instead of water.

Whenever, Paulus, you observe her with flaming face and swollen veins approaching you, you may well say, 'Myrtale drinks bays.'

$(\text { Mart. 5.4) })^{1}$ 
The Graeco-Roman world excluded women from a number of public activities, such as certain religious rituals and sacrifices. ${ }^{2}$ Moreover, women could not participate in some aspects of private life, such as theatrical performances or sport games. Late Republican and Imperial written sources inform us that women in archaic Rome were not even allowed to drink wine. Although the prohibition relates to a domestic context, it seems surprising, given the role that women played in Bacchic cult, as well as considering that, during the Republican age, they were involved with ritual practices that required wine offerings to be made, for example to Lares and Penates or Liber and Libera. ${ }^{3}$ It is also interesting that wine was offered by women, though incognito (as it was called 'milk' and the wine jar a 'honey-pot'), during the ancient ritual of Bona Dea. ${ }^{4}$ There are, therefore, those who argue that the taboo was not a real archaic custom but a creation of the Roman Republic which tried to shape 'women into chaste and obedient wives and daughters', and that it was likely to have been influenced by the Greeks. ${ }^{5}$

Nevertheless, a number of scholars from the early twentieth century assumed that the literary evidence is reliable and that women were not allowed to drink wine, relating the prohibition to feminine weakness (wine drinking led them to adultery ${ }^{6}$ ) or to the abortive properties of wine. ${ }^{7}$ These ideas - especially the relation between a wine taboo and adultery - continue to haunt much more recent research regarding the role of women in ancient Roman religious rituals. ${ }^{8}$ However, they do not stand up to critical investigation, as they do not explain why women were allowed to drink lora, passum, and other alcoholic beverages, or why drinking was commonly accepted during the Late Republican period, when adultery was still severely punished.

${ }^{2}$ E. Hemelrijk, 'Women and Sacrifice in the Roman Empire', in O. Hekster, S. Schmidt-Hofner, and C. Witschel (eds.), Ritual Dynamics and Religious Change in the Roman Empire (Leiden and Boston, MA, 2009), 253-67.

${ }^{3}$ Columella, Rust. 12.18.4; M. J. DiLuzio, A Place at the Altar. Priestesses in Republican Rome (Princeton, NJ, 2016), 45-7, 99-100; C. E. Schultz, Women's Religious Activity in the Roman Republic (Chapel Hill, NC, 2006), 133, 136.

${ }^{4}$ H. S. Versnel, 'The Festival for Bona Dea and the Thesmophoria', GE $R 39$ (1992), 32.

${ }^{5}$ For example, B. F. Russell, 'Wine, Women, and the Polis: Gender and the Formation of the City-State in Archaic Rome', GER 50 (2003), 83.

${ }^{6}$ P. Noailles, 'Les tabous du manage dans le droit primitif des Romains', in Fus et fus. Études de droit romain (Paris, 1948), 21.

${ }^{7}$ M. Durry, 'Les femmes et le vin', REL 33 (1955), 110-12.

${ }^{8}$ Schultz (n. 3), 132-3. DiLuzio (n. 3), 4. 
Other explanations of the taboo have focused on the nature of the wine that was forbidden rather than on the nature of women. For example, M. Gras noted that wine amphoras and other banquet utensils were found in female graves dated to the archaic period, which led him to the conclusion that only the consumption of temetum, meaning sacred wine, was forbidden to women, while drinking Greek oîvos or Phoenician imports, as well as other beverages unsuitable for libations, was allowed. ${ }^{9}$ According to Gras, this prohibition disappeared between the eighth and fifth century $\mathrm{BC}$, since it does not appear in the Law of the Twelve Tables, which is when imported beverages became common in Italy. ${ }^{10}$

Quite the opposite interpretation of literary evidence has recently been proposed by Hemelrijk, who argues that in the old days, wine was considered inappropriate for women except in a religious context'. ${ }^{11}$ However, this statement is based mostly on Servius, who claimed that women refrained from drinking apart from certain religious rituals. ${ }^{12}$ The source is obviously too late (fourth/fifth century $\mathrm{AD})$ to be reliable for Roman archaic customs, which means that this explanation of the taboo cannot be accepted. Instead, it is worth considering a theory proposed by $\mathrm{M}$. Bettini, who argued that the prohibition related to alcoholic wine (temetum), whereas all drinks called dulcia were allowed to women, because they were alcohol-free. ${ }^{13}$

The aim of this article is to reconsider the arguments of Gras and Bettini in the light of new archaeological evidence regarding the origins of wine consumption in Roman Italy, as well as research on the characteristics of wines that were imported to Italy in the archaic period. The first part critically re-examines the sources that mention the prohibition on women drinking wine, while the second presents evidence regarding the origins of wine production and consumption in Italy, and characteristics of archaic wines.

${ }^{9}$ M. Gras, 'Vin et société à Rome et dans le Latium à l'époque archaïque', in Modes de contacts et processus de transformation dans les sociétés anciennes (Rome, 1983), 1069-71. The duality between temetum and vinum agrees with the theory of $\mathrm{O}$. de Cazanove, according to which the Romans distinguished wine for Jupiter (a pure, new wine that had no admixtures) from the wine for Liber Pater, who was later identified with Dionysus and Bacchus: see O. De Cazanove, 'Jupiter, Liber et le vin latin', RHR 205 (1988), 255-6.

${ }^{10}$ M. Gras, Trafics tyrrhéniens archä̈ques (Rome, 1985), 382.

${ }^{11}$ Hemelrijk (n. 1), 257. This view is also held by DiLuzio (n. 3), 4.

12 Serv. Aen. 1.73.

${ }^{13} \mathrm{M}$. Bettini, 'In vino stuprum', in O. Murray and M. Tecusan (eds.), In vino veritas (London, 1995), 214-37. 


\section{Archaic prohibition according to ancient authors}

Our knowledge regarding the archaic prohibition of wine drinking by women comes from the texts, both Latin and Greek, which were written several hundred years after the supposed 'wine taboo' was abandoned, and they relate to the period of Roman history that was later mythologized. Therefore, they do not provide reliable evidence regarding archaic customs. Moreover, literature of the Late Republican and Early Imperial age tended to idealize Roman ancestors, associating their supposed personal morality with the well-being of the state. ${ }^{14}$ These texts attributed to elite women the ability to destroy the moral order and hence the security of the state. Since chastity was among the virtues most expected in elite women, their drinking was likely to have been seen as a vice. This was probably influenced by the fact that, in Greek culture, noble and virtuous women were excluded from symposia and public life in general. ${ }^{15}$

According to some scholars, the whole idea of women being forbidden to drink wine results from Greek criticism of the presence of women at Roman convivia. ${ }^{16}$ This may be the reason why Greek writers, especially those who, like Plutarch, aimed to provide a moral example, wrote about the total abstinence of Roman women in the archaic age. ${ }^{17}$ It is therefore hard to believe Dionysius of Halicarnassus' story about Romulus permitting punishment by death for a woman who drank wine, because drunkenness led to adultery. ${ }^{18}$ One may wonder what a Greek historian living during the first century BC knew about archaic Roman customs. Moreover, Dionysius tended to show the archaic Romans as similar to the Greeks, and hence might

\footnotetext{
${ }^{14}$ The best example mentioning wine being taboo to women, in an attempt to idealize archaic reality, is probably Tert. Apol. 6.4-6.

${ }^{15}$ P. Culham, 'Women in the Roman Republic', in H. I. Flower (ed.), The Cambridge Companion to the Roman Republic (Cambridge, 2004), 140-2. But the question regarding the presence of women in the Greek symposium has recently been reconsidered: see K. Topper, The Imagery of the Athenian Symposium (Cambridge, 2013), 105-34; J. Mossman, 'Plutarch's Dinner of the Seven Wise Men', in J. Mossman (ed.), Plutarch and His Intellectual World (London, 1997), 137, n. 28. For sources mentioning Greek, Etruscan, and Roman women at symposia see Plut. Demetr. 27.2-4; Plut. Pyrrh. 5.6; Plut. C. Gracch. 19.2; Petron. 73-4; Theopomp. BNF 115 F204 (the last testimony exaggerated according to M. A. Flower, Theopompus of Chios. History and Rhetoric in the Fourth Century BC (Oxford, 1994), 190-1).

${ }^{16}$ Schultz (n. 3), 133. On women at Roman convivia, see A. Rathje, 'The Adoption of the Homeric Banquet in Central Italy in the Orientalizing Period', in O. Murray (ed.), Sympotica. A Symposium on the Symposium (Oxford, 1990), 283; Russell (n. 5), 82-4.

${ }^{17}$ Plut. Comp. Lyc. Num. 3.5.

${ }^{18}$ Dion. Hal. Ant. Rom. 2.25.6.
} 
have distorted the truth. ${ }^{19}$ On the other hand, even if adultery was a severe crime that deserved the death penalty in both cultures, Dionysius was surprised that the Romans would severely punish drinking, 'which the Greeks would look upon as the least of all faults' (Ant. Rom. 2.25.6). ${ }^{20}$ Valerius Maximus, like Dionysius, related women's drinking with an immoral way of life. ${ }^{21}$

Furthermore, Pliny's statement that 'at Rome women were not allowed to drink wine' seems doubtful (Plin. $H N$ 14.89). ${ }^{22}$ It is based on just a few examples that are not explicit enough to allow such a conclusion to be drawn. For example, a legend regarding Egnatius Maetennus, who slew a woman for drinking wine and was not punished by Romulus, does not state that it was customary to kill women for drinking. ${ }^{23}$ The whole description of wine in archaic Rome, especially a story about a woman who lost her dowry for having drunk more wine than was necessary for her health and doing it without the knowledge of her husband, suggests rather that wine was used sparingly and that it was a special, rare, and precious drink. ${ }^{24}$ One should also remember that Pliny was often uncritical and looked for sensational curiosities, so the examples of killing a woman and of starving someone to death, which were unusual, were possibly mentioned here to arouse the interest of the audience, overshadowing real customs. ${ }^{25}$

However, Pliny also recalls information from Cato, according to which Roman males used to kiss women to check whether they smelled of temetum. Cato was famous for his conservatism and being a guardian of old Roman traditions; he wrote Origines, the history of Rome from the time of its foundation, and it is commonly accepted that his testimonies are credible. ${ }^{26}$ Therefore, if anyone was to provide reliable

${ }^{19}$ Culham (n. 15), 140; M. Fox, 'History and Rhetoric in Dionysius of Halicarnassus', $7 R S 83$ (1993), 34-6.

${ }^{20}$ Translation from E. Cary (ed. and trans.), Dionysius of Halicarnassus. Roman Antiquities, Volume I. Books 1-2 (Cambridge, MA, 1937).

${ }^{21}$ Val. Max. 2.1.5.

${ }^{22}$ Translation from H. Rackham (ed. and trans.), Pliny. Natural History. Books 12-16 (Cambridge, MA, 1945).

${ }^{23}$ The same story appears in Val. Max. 6.3.9.

${ }^{24}$ Plin. HN 14.88-91.

25 A. Doody, Pliny's Encyclopedia. The Reception of the Natural History (Cambridge, 2010), 26-7; H. Rackham, 'Introduction', in Pliny. Natural History in Ten Volumes (Cambridge, MA, and London, 1979), ix-x.

${ }^{26}$ W. D. Hooper, 'Introduction', in Cato and Varro on Agriculture (Cambridge, MA, and London, 1934), ix-xiii; T. Cornell, The Fragments of the Roman Historians (Oxford, 2013), 23-5. 
information regarding the remote Roman past, it was the author of De agricultura.

It is notable that Pliny used the word temetum (not vinum), probably following Cato. This was an old term that was no longer in use during the first century AD (as an explanation concerning its meaning was deemed necessary). ${ }^{27}$ Linguistic studies suggest that temetum originally referred to an alcoholic beverage made from mountain ash (sorbus aucuparia), which in the dialects of Lombardy and Piedmont is called temel, tumel, or temar. Moreover, the root temer is associated with the word tamaro, which means Vitis sylvestris (the wild grapevine) in the modern Tuscan dialect. Therefore, temetum was an alcohol made of fermented rowan and later on it started to designate grape wine, initially made of wild grapes. ${ }^{28}$ Under Greek influence (during the seventh and sixth centuries BC) the use of this word ceased, and vinum became the word for an alcoholic beverage made from fermented grape juice. ${ }^{29}$ However, the root temet survived in Latin in the adjectives temulentus and abstemius, which referred to the state of intoxication.

The word temetum, with an explanation, is also used by Aulus Gellius who quotes Cato (On the dowry) and probably other authors. ${ }^{30}$ We may suppose that Cato, a pioneer in Latin literature, used the correct Latin terms, so it is meaningful that he wrote about temetum, not vinum. According to Gellius' Noctes Atticae (which describes the supposed taboo most extensively), women did not drink temetum but could consume lora (a drink that was obtained through the fermentation of water and the remnants that were left after the squeezing of grapes), passum (raisin wine), murrina (wine flavoured with myrrh and other spices), and other sweet wines. Aulus Gellius also recalls information (again from Cato) regarding the custom of kissing women in order to detect whether they have drunk wine, adding that women were severely punished for drinking, as they were for adultery (meaning the death sentence). ${ }^{31}$ Added to this could be Polybius' remark that women

${ }^{27}$ Plin. HN 14.90.

${ }^{28}$ V. Bertoldi, Linguistica storica. Questioni di metodo (Naples, 1942), 165-9.

${ }^{29} \mathrm{~A}$. Ciacci, 'La ricostruzione del paesaggio vitivinicolo antico: l'indagine sui vitigni e la circolazione varietale', in G. di Pasquale (ed.), Vinum nostrum. Arte, scienza e miti del vino nelle civiltà del Mediterraneo antico (Florence, 2010), 77.

${ }^{30}$ Gell. NA 10.23.

${ }^{31}$ Gell. NA 10.23. The custom of kissing women in relation to their supposed wine-drinking ban also appears in Plut. Quaest. Rom. 6, but the author also gives other explanations regarding its origin. For an explanation regarding passum, deuteria, etc., see A. Tchernia, 'La vinification des Romains', in G. Garrier (ed.), Le vin des historiens. Actes du Ier symposium Vin et histoire, 19- 
were forbidden to drink wine, but they could drink passum, as well as Cicero's comment that they abstained from temetum. ${ }^{32}$ These laconic testimonies suggest that both Polybius and Cicero based their comments on a similar source or sources to Aulus Gellius.

In summary, there is no reliable testimony confirming that women in the Archaic age could not drink wine at all. The literature suggests that the prohibition did not concern wine in general, but rather particular types of wines.

\section{Temetum, vinum, or dulcia? What did the Romans drink during the archaic age?}

The assumption that the Romans saw a difference between local and sacred temetum and imported vinum requires proof that wine-making existed in central Tyrrhenian Italy before contact with the Greeks. The origins of wine-making in Italy are usually dated to somewhere between the Mycenaean era and Greek colonization. ${ }^{33}$ Owing to the scarcity of evidence from before the eight century $\mathrm{BC}$, the idea that the inhabitants of Italy became acquainted with wine in the eighth or seventh century BC thanks to contacts with Greek colonists seemed quite logical. ${ }^{34}$ However, study of recent archaeobotanical, genetic, and archaeological evidence shows that the beginnings of Roman viticulture and wine-making should be placed earlier, and also emphasizes its local rather than foreign origins.

Grape seeds, if their state of preservation is good, allow us to verify whether they represent a cultivated or a wild vine variety. ${ }^{35}$ The analysis of samples from Italy has proved that domesticated grapes were known in central Italy in the Bronze Age. The oldest seeds, dated to the

21 mai 1989 (Suze-la-Rousse, 1990), 65; A. Dalby, Food in the Ancient World from A to $Z$ (London and New York, 2003), 352.

${ }^{32}$ Polyb. Hist. 6.11a.4=Ath. 440e-f; Cic. Rep. 6.6.

${ }^{33}$ F. Delpino, 'Viticoltura, produzione e consume del vino nell'Etruria protostorica', in A. Ciacci, P. Rendini, and A. Zifferero (eds.), Archeologia della vite e del vino in Etruria (Siena, 2007), 136.

${ }^{34}$ Ibid.; T. Unwin, Wine and the Vine. An Historical Geography of Viticulture and the Wine Trade (London and New York, 1991), 82; M. Cristofani, 'Vino e simposio nel mondo etrusco arcaico', in P. Scarpi (ed.), Storie del vino (Milan, 1991), 70.

35 C. Zohary, 'Domestication of Vitis vinifera in the Near East', in P. E. McGovern, S. J. Fleming, and S. H. Katz (eds.) The Origins and Ancient History of Wine (Amsterdam, 1996), 27; A. Lentini, 'New Archaeobotanical Data on the Cultivation of Vitis ssp. at Pyrgos-Mavrorachi', in Notes of Kinyras, Since 4th Millennium BC and Evidence from Erimi (Nicosia, 2009), 59. 
Middle Bronze Age, that represent a cultivated vine were discovered in San Lorenzo a Greve, ${ }^{36}$ while remains of domesticated grapes from the Late Bronze Age were found in Chiusi, Livorno-Stagno, and Tarquinia. ${ }^{37}$ This evidence indicates that vine cultivation might have taken place in Etruria during the Bronze Age. However, seeds of domesticated grapes from this period were always found together with seeds of Vitis sylvestris, so we cannot exclude that domesticated seeds came from imported fruits. ${ }^{38}$

A DNA study of modern Vitis sylvestris showed that specimens that grew near inhabited areas in antiquity differ from those that were found in uninhabited contexts. In addition, their population had more female and hermaphrodite specimens, whereas in the natural environment males should predominate. This indicates that people influenced the wild vine, for example by protecting it and selecting female and hermaphrodite plants (over male ones that do not bear fruit), as early as the Bronze Age, which provides an argument for the local domestication of this plant. ${ }^{39}$ Considering that two specimens of Vitis sylvestris from the area of Ghiacco Forte presented a genetic resemblance to the vines that are cultivated today, we may conclude that the domestication of Vitis in certain parts of Etruria had local origins. ${ }^{40}$ It is worth mentioning that, at the beginning of the Iron Age and maybe as far back as the end of the Bronze Age, the inhabitants of Etruria used billhooks (pennati), which were cutting tools that were commonly used for viticulture. ${ }^{41}$

This may be confirmed by the analysis of the agricultural techniques that were used by ancient populations. The Etruscans used a technique

${ }^{36}$ B. Aranguren et al., 'Testimonianze dell uso della vite nell Bronzo Medio: nuovi dati da San Lorenzo a Greve (Firenze)', in A. Ciacci, P. Rendini, and A. Zifferero (eds.), Archeologia della vite e del vino in Toscana e nel Latium. Dalle tecniche dell'indagine archeologica alle prospettive della biologia molecolare (Florence, 2012), 125-31.

${ }^{37}$ M. Mariotti Lippi, M. Mori Secci, and C. Bellini, 'L'archeobotanica, e lo studio della vite nella Preistoria in Toscana', in Ciacci, Rendini, and Zifferero (n. 36), 122; Delpino (n. 33), 134.

${ }^{38}$ G. Forni, 'La matrice euromediterranea della nostra viticoltura: la prospettiva pluridisciplinare', in Ciacci, Rendini, and Zifferero (n. 36), 110; C. Cicirelli et al., 'La vite a Poggiomarino, Longola: un contesto di vinificazione dell'Età del Ferro', in P. G. Guzzo and M. P. Guidobaldi (eds.), Nuove ricerche archeologiche nell'area vesuviana (scavi 2003-2006). Atti del convegno internazionale, Roma, 1-3 febbraio 2007 (Rome, 2008), 574-5.

${ }^{39}$ S. Imazio et al., 'Progetto VINUM: metodi di analisi del genoma e primi risultati', in Ciacci, Rendini, and Zifferero (n. 36), 618-20.

${ }^{40}$ A. Ciacci, 'La ricostruzione del paesaggio vitivinicolo antico: l'indagine sui vitigni e la circolazione varietale', in di Pasquale (n. 29), 75.

${ }^{41}$ F. Delpino, 'I Greci in Etruria prima della colonizzazione euboica: ancora su crateri, vino, vite e pennati nell'Italia centrale protostorica', in M. Pallottino and G. Bartoloni (eds.), Le necropoli arcaiche di Veio (Rome, 1997), 186-90; F. Delpino, 'Viticoltura, produzione e consume del vino nell'Etruria protostorica', in Ciacci, Rendini, and Zifferero (n. 36), 192, 196. 
of high-training of vines supported on trees, whereas, if they had taken all their viticultural know-how from the Greeks, they would have been more likely to use the low-training (vines supported on sticks) that was typical for the Greeks. ${ }^{42}$ The findings of the remains of ancient vineyards in Etruria, Latium, and the Etruscan areas of Campania suggest the use of high-training separately from low-training from their origin until at least the fourth century BC. ${ }^{43}$ This dualism between the high-training of arbustum (Etruscan) and low-training of vinea (Greek) resembles the one between temetum and vinum.

Notwithstanding these observations, human interference in the growth of the vine is not always associated with wine production. However, in Livorno-Stagno and in Chiusi the archaeobotanical remains of cornel (a plant that has little nutritional value) were attested together with grape seeds dated to the second half of the second millennium BC. ${ }^{4}$ Since the Bronze Age inhabitants of Italy were familiar with the fermentation of cornel, ${ }^{45}$ it is unlikely that they would have ignored grape fermentation into alcohol. Furthermore, from at least the last decades of the ninth century BC Etruria produced tableware that was freely inspired by Greek sympotic pottery and it is commonly assumed that it was used for drinking wine. ${ }^{46}$ They also made certain types of vessels (kyathos, capeduncola, and anforetta a spirale) that were typical of Etruscan and Latin traditions between the Late Bronze Age/Early Iron Age and the sixth century BC and had nothing to do with the Greek world. According to $\mathrm{M}$. Torelli, these pottery types should be associated with temetum, the alcoholic beverage that was known in Italy earlier than the Greek oivos. It might have been a local invention or have resulted from contacts with the Mycenaeans in the Bronze Age. ${ }^{47}$

${ }^{42}$ E. Sereni, Per la storia delle più antiche tecniche e della nomenclatura della vite e del vino in Italia (Florence, 1964), 128-31; C. Cerchiai, Nettare di Dioniso. La vite e il vino attraverso le parole degli autori antichi (Rome, 2013), 277.

${ }^{43}$ This technique disappeared around this period: see R. Volpe, 'Vino, vigneti et anfore in Roma repubblicana', in V. Jolivet et al. (eds.), Suburbium II. Il suburbio di Roma dalla fine dell'età monarchica alla nascita del sistema delle ville (V-II secolo a.C.) (Rome, 2009), 373.

${ }^{44}$ Mariotti Lippi, Mori Secci, and Bellini (n. 37), 122.

${ }^{45}$ Forni (n. 38), 108.

${ }^{46}$ Delpino (n. 33), 138-9; Delpino (n. 41), 192-3. Contra: P. Ruby, 'Tarquinia, entre la Grèce et Sala Consilina: éléments pour l'étude de la circulation des biens de prestige dans l'Italie centrale et méridionale protohistorique', MEFRA 105 (1993), 801, 805-9, 818-20.

${ }^{47} \mathrm{M}$. Torelli, 'Primi apunti per un'antropologia del vino degli Etruschi', in C. Cremonesi and D. Tomasi (eds.), L'avventura del vino nel Bacino del Mediterraneo. Itinerari storici ed archeologici prima e dopo Roma (Conegliano 2000), 93-100. 
To summarize, new approaches (both archaeobotanical and genetic) clearly reduce the importance of Greek influence on the origins of wine production on the Apennine peninsula. It now seems more likely that it was a local invention, which may be dated back (though not certainly) as early as the Bronze Age. The Etruscans probably used wine at the end of the ninth century BC, and nothing suggests that the Romans were unfamiliar with this beverage. During the archaic period an alcohol made of fermented grapes was called temetum, and its use might have been subject to certain taboos. In light of the abovementioned evidence, Gras's theory, according to which women were not allowed to drink temetum (a local wine that served for religious purposes), seems to be strongly supported. However, it should also be made clear what types of imported wines reached Italy in the archaic age and what their characteristics were. Were they strong, aromatic wines, or rather sweet, low-alcohol drinks that could be included into the category of dulcia, which was allowed, according to Bettini?

\section{Imported wines and their characteristics}

It is possible to determine what types of wines were imported to Italy during the archaic age thanks to archaeological evidence in the form of wine containers. Amphoras from Attica, Laconia, Corcyra, Clazomenae, Lesbos, Chios, Mende, Thasos, Samos, Miletus, Peparethos, and probably Euboea were widely attested in central Tyrrhenian Italy between the seventh and fifth centuries BC, mostly in Etruscan cemeteries in Cerveteri, Vulci, Tarquinia, and Veii, and in harbours, including Gravisca, Pyrgi and Regisvilla. ${ }^{48}$ Although

${ }^{48}$ C. Albore Livadie, 'La situazione in Campania', in M. Cristofani et al. (eds.), Il commercio etrusco arcaico (Rome, 1985), 138-45; N. Di Sandro, 'Appunti sulla distribuzione delle anfore commerciali greche in Campania tra l'VIII sec. e il 273 a.C.', AION(archeol) 3 (1981), 11-12; A. Marangou-Lerat, 'Le plus agréable des vins grecs', in Cremonesi and Tomasi (n. 47), 72; M. Slaska, 'Le anfore da trasporto a Gravisca', in Cristofani et al. (this note), 19-21; F. Sacchetti, Les amphores grecques dans le nord de l'Italie. Échanges commerciaux entre les Apennins et les Alpes aux époques archaïque et classique (Paris and Aix-en-Provence, 2013), 64-5, 75-6, 80-1, 93-5, 101-2; A. Doulgéri-Intzessiloglou and Y. Garlan, 'Vin et amphores de Péparéthos et d'Ikos', BCH 114 (1990), 388; F. Boitani, 'Cenni della distribuzione delle anfore da trasporto arcaiche nelle necropoli dell'Etruria meridionale', in Cristofani et al. (this note), 23; M. A. Rizzo, Le Anfore da trasporto e il commercio etrusco arcaico 1. Complessi tombali dall'Etruria meridionale (Rome, 1990), 22-6; M. Slaska, 'Gravisca: le ceramiche comuni di produzione Greco-orientale', in Les céramiques de la Grèce de l'Est et leur diffusion en Occident (Paris, 1978), 228-30; G. Colonna, 'Anfore da trasporto arcaiche: il contributo di Pyrgi', in Cristofani et al. (this note), 6-14; C. Morselli and E. Tortorici, 'La situazione di Regisvilla', in Cristofani et al. 
there is no consensus regarding the content of the archaic amphoras, it seems almost certain that the containers produced on Chios, Lesbos, Thasos, Peparethos, and Corcyra, and in Mende carried wine. ${ }^{49}$ Therefore, the Etruscan consumption of Greek wines in the archaic period seems certain.

Amphora evidence from Latium dated to the archaic period is less abundant: in the three Roman necropoleis of Ficana, Laurentina, and Decima all of the amphoras were of west Phoenician origin, except for one fragment of Corinthian A type. ${ }^{50}$ Other fragments of Corinthian A amphoras were found in the Roman suburbs, ${ }^{51}$ while a single fragment of Chian container was discovered on the Palatine Hill. ${ }^{52}$ This is all the known evidence regarding Greek amphoras dated to the archaic period found in areas inhabited by the Romans. However, the discoveries from certain residential areas that might contain fragments of Aegean transport containers have yet to be fully investigated. ${ }^{53}$ Moreover, in the Temple of Castor and Pollux in the Forum Romanum a few fragments of Corinthian A, A', and B, and Samian type, and one Mendean amphora were discovered. They date between 550 and $300 \mathrm{BC}$, which means that at least some of these fragments were from the archaic age. ${ }^{54}$ Nevertheless, considering the fact that it is questionable whether Corinthian A vessels were used to transport wine, it seems that only one fragment of a Greek wine amphora that can be certainly dated to the archaic period has been found in Rome. ${ }^{55}$ This does not allow us to state that the Romans certainly drank Greek wines, but it would be surprising if they did not have access to these beverages, considering their popularity among their neighbours. Furthermore, amphora evidence leaves no doubt that Phoenician wines were present on Roman tables, as well

(this note), 31-3; G. Paolucci, 'Le anfore tipo "tolle": contributo al commercio di vino nell'Etruria settentrionale interna', in G. M. Della Fina (ed.), Gli Etruschi e il Mediterraneo. Commerci e politica (Rome, 2006), 423-4.

${ }^{49}$ Sacchetti (n. 48), 27-8, 37, 51-2, 64, 74-5, 80, 93, 101.

${ }^{50}$ Gras (n. 9), 1068; Sacchetti (n. 48), 30.

${ }^{51}$ H. Di Giuseppe, 'I reperti', in A. Carandini, M. T. D'Alessio, and H. Di Giuseppe (eds.), La fattoria e la villa dell'Auditorium nel quartiere Flaminio di Roma (Rome, 2006), 207, table 20; H. Di Giuseppe, 'I reperti, le clasi ceramiche. Periodi 3 e 4', in Carandini, D'Alessio, and Di Giuseppe (this note), 400.

${ }^{52}$ Sacchetti (n. 48), 76; F. Zevi, 'La situazione nel Lazio', in Cristofani et al. (n. 48), 119.

${ }^{53}$ Sacchetti (n. 48), 30.

${ }^{54}$ K. Slej, 'Transport Amphorae', in K. Slej and M. Cullhed (eds.), The Temple of Castor and Pollux II, 2. The Finds and the Trenches (Rome, 2008), 204-8.

${ }^{55}$ Sacchetti (n. 48), 27-8. 
as Etruscan ones, which were produced and exported between the end of the seventh century and the fourth century BC. ${ }^{56}$

Unfortunately, we know very little about the characteristics of Phoenician and Etruscan wines, which is mostly due to the lack of written sources. Scholars studying wines from the Levant, Mesopotamia, and Punic Africa mention neither the types nor the characteristics of wines that were produced in these regions. ${ }^{57}$ Assyrian cuneiform tablets from Nimrud dated to the early first millennium $\mathrm{BC}$ are one of very few sources that shed some light on this issue, mentioning that the Assyrians produced sweet/good white wine, bitter wines, strong wine, and 'early wine'. ${ }^{58}$ However, this does not allow us to form any developed hypotheses regarding the taste and characteristics of these beverages. It seems that the Hittites produced raisin wine and it is clear that the Phoenicians were also familiar with this custom, given recipes for passum copied by Columella from Mago (a Carthaginian 'oenologist'). ${ }^{59}$ One of them produced a low-alcohol or even an alcohol-free beverage (too much sugar in the must inhibited fermentation). ${ }^{60}$ However, there is no evidence that the Romans knew of passum as early as the archaic age, as our evidence for the popularity of raisin wines in the Roman world comes from the Imperial period and mostly relates to imported beverages, such as Cretan, Cilician, and African varities, as well as local ones that did not enjoy any particular fame. ${ }^{61}$

On the basis of a passage from Achilles Tatius, F. Salviat attributes a Phoenician origin to certain Greek crus, such as Byblinos, Chian, Maroneian, and Thracian. Given that each vine species produces a beverage of certain, original qualities, it is likely that some parts of Phoenician and Greek wine production were similar. Furthermore, the Bible and Egyptian papyri mention wine from Lebanon and state

\footnotetext{
${ }^{56} \mathrm{M}$. Bats, 'L'arrivée du vin étrusque sur le litoral del Méditerranée nord-occidentale $\left(\mathrm{VI}^{\mathrm{e}}-\mathrm{V}^{\mathrm{e}}\right.$ s. av. J.-C.)', in Ciacci, Rendini, and Zifferero (n. 36), 377.

${ }^{57}$ See e.g. J. A. Greene, 'The Beginnings of Grape Cultivation and Wine Production in Phoenician-Punic North Africa', in McGovern, Fleming, and Katz (n. 35), 311-22; A. Leonard Jr, 'Canaanite Jars and the Late Bronze Age Aegeo-Levantine Wine Trade', in ibid., 233-54; M. A. Powell, 'Wine and the Vine in Ancient Mesopotamia: The Cuneiform Evidence', in ibid., 97-122.

${ }^{58}$ D. Stronach, 'The Imagery of the Wine Bowl: Wine in Assyria in the Early First Millennium B.C.', in McGovern, Fleming, and Katz (n. 35), 180.

${ }^{59}$ R. L. Gorny, 'Viticulture and Ancient Anatolia', in McGovern, Fleming, and Katz (n. 35), 136-7, 147-58.

${ }^{60} \mathrm{~S}$. Kourakou-Dragona, La vigne et le vin dans le monde grec ancien (Athens, 2013) 5-8, 52-3.

${ }^{61}$ Plin. $H N$ 14.81.
} 
that it was a high-quality drink. Considering that it was able to survive transportation to Egypt and that Phoenician wines were consumed diluted, we may assume that they were strong wines. ${ }^{62}$ In summary, if Roman women were permitted to drink Phoenician wines, they must have been allowed to drink alcohol.

Literary evidence regarding Greek wines, such as Chian, Lesbian, Mendean, and Thasian, is abundant, but we should remember that it comes from the classical age and onwards. Therefore, we cannot be certain that all Greek wines imported to Italy during the eight and seventh centuries BC shared the same characteristics as in the classical, Hellenistic, and Roman periods. Nevertheless, since no evidence suggesting that archaic and classical Greek wines differed considerably has so far been found, we can assume that their main characteristics did not change much over time.

Greek wines such as Chian, Lesbian, and Mendean were white

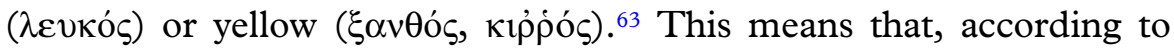
our standards, they would be described as white beverages that had matured for a considerable time: as a consequence of long maturation, white wines may become darker, gaining yellow and amber hues. ${ }^{64}$ Wine from Thasos was probably strong, since it stayed in the head for a long time. ${ }^{65}$ Plautus, writing about Chian, Lesbian, Thasian, and Leucadian, calls them old and toothless (vetustate vino edentulo aetatem), which should be understood as 'mellowed by age', thus, old and mature. ${ }^{66}$ From other sources we learn that these wines were old and had a pleasant aroma. ${ }^{67}$ In addition, numerous literary testimonies confirm that they were prepared without an admixture of seawater ( $\dot{\alpha} \theta \dot{\alpha} \lambda \alpha \sigma \sigma 01$, maris expers). ${ }^{68}$

${ }^{62}$ F. Salviat, 'Origine orientale et diffusion des cépages grecs', in F. Salviat and A. Tchernia, Vins, vignerons et buveurs de l'antiquité (Rome, 2013), 118-21; F. Salviat, 'Vignes et vins anciens de Maronée à Mendé', in ibid., 80, 86-7.

${ }^{63}$ Gal. MM 10.835K; Comp. Med. Loc. 13.513K; Vict. At. 94; Orib. Syn. 4.3.1; Col. Med. 3.4.1, 5.6.31, 5.6.45; Dsc. Mat. Med. 25.698; Salviat, 'Vignes' (n. 62), 91, 97-8.

${ }^{64}$ A. Tchernia and J.-P., Brun, Le vin romain antique (Grenoble, 1999), 132-3 and fig. 173.

${ }^{65}$ Ar. Eccl. $1118-19$.

${ }^{66}$ Plaut. Poen. 699-700. W. G. Arnott, 'Studies in Comedy, II: Toothless Wine', GRBS 11 (1970), 47.

${ }^{67}$ Hippoc. Morb. 22.323K; Ath. 29C. Ath. 28F, 29B; Plaut. Poen. 699-700; Clem. Al. Paed. 2.2.30.2; Orib. Col. Med. 5.6.45; Aet. 7.112.34 and 47 .

${ }^{68}$ Dsc. Mat. Med., 5.11, 25.698K.; Gal. Ant. 14.162K; Aet. 7.112.47 and 51-2; Paul. Aeg. Epit. Med. 7.16.7; Serm. 2.15; Gal. MM 25.832-3K; F. Salviat, 'Le vin de Thasos: amphores, vin et sources écrites', in J.-Y. Empereur and Y. Garlan (eds.), Recherches sur les amphores grecques (Athens, 1986), 175. 
These characteristics, as well as some other clues, suggest that the best Greek wines resembled modern vins oxidatifs or French vin de voile or vin jaune. These wines mature for a couple of years under a white film of yeast, known as flor, in the production of fino sherry, or voile in French. This is created when wine is kept for a couple of years in wooden casks that are not entirely full, which enables oxidation of the wine and the formation of certain molecules, such as sotolon, which are responsible for the specific taste of these wines, described as fresh bread, curry, or walnuts. ${ }^{69}$ For example, Philyllius mentions Xiov $\sigma \alpha \pi \rho o ́ v$, which generally means rotten, putrid, or old in the negative sense, whereas in terms of wine it is translated as old and mellow. ${ }^{70}$ According to Dalby, this epithet may describe wine that was made of grapes that have been attacked by a noble rot. ${ }^{71}$ However, Kourakou-Dragona argues that it is impossible to make wine from grapes that have been attacked by Botrytis without the use of sulphur dioxide, and there is no evidence that people in classical antiquity added this compound to wine. She also rejects the common translation of the word $\alpha v \theta o \sigma \mu i \alpha \varsigma$ as 'redolent of flowers', and relates it to fleur de vin, which means the film of yeast that may appear on the surface of wine. ${ }^{72}$ This film of yeast is mentioned in Geoponica as öv $\theta 0 \varsigma$, whereas Pliny and Columella call it flos vini. ${ }^{73}$ According to Kourakou-Dragona, the term $\sigma \alpha \pi \rho$ ó $\varsigma$ should be associated with the film of yeast, which means that Chian wine could be included in the category of vins oxidatifs. ${ }^{74}$

A similar conclusion may be drawn in the case of wine from Lesbos. A passage from Archestratus, preserved in Deipnosophists, mentions

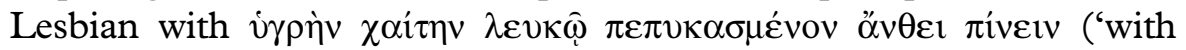
hoary head indeed, whose moist locks are crowned with a white bouquet'). ${ }^{75}$ Salviat suggests that this metaphor refers to the film of yeast that is formed on the surface of the wine during its maturation. ${ }^{76}$

${ }^{69}$ J. Robinson, The Oxford Companion to Wine (Oxford, 2006), 750.

${ }^{70}$ Phil. fr. $23(24)=$ Ath. 31A.

71 A. Dalby, Siren Feasts. A History of Food and Gastronomy in Greece (London, 1997), 101.

${ }^{72}$ Kourakou-Dragona (n. 60), 65-70. The same interpretation was proposed by García Soler: see M. J. García Soler, 'Apuntes para un estudio sobre el vino en la comedia griega', in J. Maldonado Rosso (ed.), Actas del I Simposio de la Asiciación Internacional de Historia y Civilización de la vid y el vino 1 (El Puerto de Santa María, 2001), 259; and M. J. García Soler, 'Los vinos en la comedia griega', DUORO: Estodios $\mathcal{E}$ documentos 7 (2002), 54-5.

${ }^{73}$ Geopon. 7.15, 6; Plin. HN 14.136; R.R. 12.30.

${ }^{74}$ Kourakou-Dragona (n. 60), 88-9.

${ }^{75}$ Fr $59 \mathrm{Ri}=$ Ath. 29B.

${ }^{76}$ Salviat (n. 68), 179. 
This hypothesis may be confirmed by the fact that this wine is called $\dot{\alpha} v \theta 0 \sigma \mu i \alpha \varsigma$ by Longus. ${ }^{77}$ Furthermore, numerous sources emphasize that Thasian wine was very fragrant ( $\varepsilon \dot{v} \omega \dot{\delta} \eta \varsigma)$ and its aroma resembled the fragrance of apples, which, according to Kourakou-Dragona was typical of vins oxidatifs. ${ }^{78}$ It is worth mentioning that beverages that matured under the film of yeast must have been strong, because otherwise they would turn into vinegar due to the oxidation processes. Moreover, they were not seasoned with seawater, which could only improve the taste of weak and watery wines, because seawater would stop the positive effects of oxidation. ${ }^{79}$

Summing up, all literary evidence indicates that Greek wines that were imported to Italy in the archaic age were old, aromatic, and strong beverages. There is nothing to suggest that they had a low alcohol content or no scent, or that they could be included in the category of dulcia. Considering that Phoenician beverages were similar to Greek ones, it seems that Etruscan and Roman women drank strong and aromatic imported wines, which means that there is nothing to indicate that they were banned from drinking alcohol. Again, the explanation by Gras, according to which Roman women could not drink the religious wine of Jupiter (temetum), seems more plausible than the one proposed by Bettini.

\section{Conclusions}

In the light of the evidence presented above, the hypothesis of Gras regarding wine drinking by Roman women seems more acceptable than Bettini's, given that fewer questions are left unanswered. It seems that the archaic wine taboo had a religious character and was associated only with temetum, which referred to the sacred wine of Jupiter, made probably from not fully domesticated, unpruned vines. This beverage, which originated in Italian tradition before Greek colonization, was prohibited to women. Those who broke the taboo were punished by death. However, during the archaic age women were allowed to drink alcohol beverages, such as wines imported from Greece and Phoenicia, spiced wines, lora, and sweet beverages

\footnotetext{
${ }^{77}$ Longus 4.10.3.

${ }^{78}$ Paed. 2.2.30.2; Ar. Eccl. 1118-19. CAF fr. 82 Kock. Kourakou-Dragona (n. 60), 86.

${ }^{79}$ Kourakou-Dragona (n. 60), 74.
} 
(dulcia) such as passum. These drinks were inappropriate for libations and other religious usages, because they were impure. ${ }^{80}$

When wine consumption became more popular, which was probably associated with the spread of sympotic practices, the prohibition disappeared. This might have been associated with the fact that wine became commonly available and was no longer a rare and sacred drink. Nonetheless, since Roman religious practices were rather conservative, the taboo remained in certain religious rituals. ${ }^{81}$ During the Late Republican and Early Imperial period certain writers evoked the prohibition, but they were no longer aware of its original cause and meaning. The popular moral renewal and the search for moral examples in archaic times resulted in the association of wine drinking with immoral behaviour. Therefore, it seems that Late Republican and Early Imperial written sources transmitted a distorted understanding of archaic Roman traditions regarding wine drinking, which resulted in a common and erroneous opinion that women in the archaic age were not permitted to drink alcohol.

PAULINA KOMAR

Cardinal Stefan Wyszynski University in Warsaw, Poland p.komar@uksw.edu.pl

${ }^{80}$ Gras (n. 9), 1072; De Cazanove (n. 9), 255-6.

${ }^{81}$ Such as the cult of Bona Dea and the funerary rites of the Vestals: see Bettini (n. 13), 228-30; Gras (n. 9), 1072. 